\title{
World Council of Churches involvement in the efforts for the recognition of the Armenian Genocide
}

\author{
DANIEL BUDA*
}

The Executive Committee of the World Council of Churches (WCC) gathered in Armenia from June $8^{\text {th }}$ to June $12^{\text {th }} 2015$, hosted by the Armenian Apostolic Church, Mother See of Holy Etchmiadzin at the invitation of His Holiness Karekin II, Supreme Patriarch and Catholicos of all Armenians, issued a statement on the centenary of the Armenian genocide. The statement was read by WCC moderator Dr. Agnes Aboum (Anglican Church of Kenya) at a public service of remembrance in Yerevan on 10 June and shared by WCC leadership in a meeting with the president of the Republic of Armenia Sezh Sargyan on the same day.

The text the statement mentions some of the "many other occasions" in which different WCC governing bodies or commissions called for recognition of the Armenian genocide and encourage WCC constituency to participate in future events related to the celebration of the Armenian genocide. It states also that the Executive Committee of WCC felt encouraged by in issuing this statement by His Holiness Pope Francis' public recognition on 12 April 2015 of the mass killing of an estimated 1.5 million Armenians as genocide.

It is essential that this statement mentions, along with the Armenian genocide, also "genocidal acts against other - mostly Christian - communities of Aramean, Chaldean, Syrian, Assyrian and Greek descent, which have blighted history at the beginning of the $20^{\text {th }}$ century."

The statement ends with a call to the international community and to WCC's member churches and to all people of faith and good will to "re-commit to the prevention of genocide and all crimes against humanity."

\section{WCC efforts for the recognition of the Armenian genocide}

There is a long history of WCC involvement in the efforts for the recognition of the Armenian genocide. The Armenian Apostolic church became a member of WCC in 1962, when Armenia was part of the Soviet Union. Already in 1979, in a session of the UN Human Rights Commission, the WCC Commission of the Churches on International Affairs called for recognition of the Armenian genocide by the United Nations with reference to

\footnotetext{
* Daniel Buda, Rev. PhD Associated Professor at the "Andrei Şaguna" Faculty of Orthodox Theology, "Lucian Blaga" University of Sibiu, Romania. Address: Mitropoliei 20, 550179 Sibiu, Romania; e-mail: daniel77bde@yahoo.de.
} 
the "Revised and Updated Report on the Question of the Prevention and Punishment of the Crime of Genocide."

A minute adopted at the 6th Assembly of the WCC held in 1983 in Vancouver acknowledged that "The silence of the world community and deliberate efforts to deny even historical facts have been consistent sources of anguish and growing despair to the Armenian people, the Armenian churches and many others."

In 1984, WCC published a document called Armenia: the Continuing tragedy which helped making known the history and plight of the Armenian people. In 2005, the Central Committee of WCC underlined in a statement that "from the Christian perspective, the path towards justice and reconciliation requires the recognition of the crime committed as a sine qua non condition for the healing of memories and the possibility of forgiveness. Forgiveness does not mean forgetting but to look back with the intention to restore justice, the respect for human rights and relationships between perpetrations and victims."

In a public statement of 11 April 2005, the Presidium of the Conference of European Churches joined the WCC in inviting all its member churches "to make April 24 a Day of Memory of the Armenian Genocide and to consider further appropriate actions related to the 90 years Commemoration of the Armenian Genocide." The Conference of European Churches (CEC) Presidium further urged "the Turkish government to initiate a process of reconciliation between the Turkish and Armenian peoples, in which the recognition of guilt and the proclamation of the truth need to be integral elements."

A "Message for the Armenian Genocide Remembrance Day" dated 13 April 2011, jointly signed by WCC and CEC General Secretaries "call upon all brothers and sisters of faith in Jesus Christ to join with the Armenian people in offering prayers for Armenians and other victims of the genocide."

The present General Secretary of WCC, Rev Dr. Olav Fykse Tveit, during his first visit to Armenia as WCC General Secretary (21-24 September 2011) visited the Monument of the Armenian Genocide and attended a memorial service in the memory of the victims of the genocide. He declared with this occasion: "As General Secretary of WCC, I am really moved to be here in this sacred place for all Armenians. I ensure you all that I will continue the efforts of my predecessors for the recognition of this tragedy of the Armenian people."

The $10^{\text {th }}$ WCC 10th Assembly in 2013 in Busan adopted a "Minute" on the 100th Anniversary of the Armenian Genocide. It contents a short his- 
torical introduction: "During the year 1915-1916, about 1.5 million Armenians were massacred and thousands more were displaced or deported from the Ottoman Empire in present-day Turkey. The <Armenian Diaspora $>$ today, scattered in different parts of the world, represents the greatest effect of the genocide as more than eight million Armenians now live outside Armenia. Even after almost a century, the Armenian Genocide still has serious implications for the Armenian people, as well as the international community. Although most of the survivors of the Armenian Genocide have passed away, the Armenian people continue to demand recognition and reparation for the suffering and injustice inflicted upon their ancestors." It concludes as the following: "Therefore, the 10th Assembly of the World Council of Churches meeting in Busan, Republic of Korea, from 30 October to 8 November 2013, therefore requests the general secretary to:

1. Organize in 2015 , around the commemorative $100^{\text {th }}$ anniversary date 24 April 2015, an international conference in Geneva on the recognition of and reparation for the Armenian Genocide with the participation, among others, of WCC member churches, international organizations, jurists, historians and human rights defenders;

2. Organize an ecumenical prayer service commemorating the victims of the Armenian Genocide at the cathedral of Geneva in conjunction with the international conference; and

3. Invite member churches of the WCC to pray in memory of the Armenian martyrs around the dates of the international conference and also for recognition of the Armenian Genocide."

WCC General Secretary attended also the official commemoration of the 100th Anniversary of the Armenian Genocide and canonization of the martyrs in Yerevan, Armenia, on 21-25 April 2015. 